\title{
17. OXYGEN-ISOTOPE COMPOSITION OF SECONDARY SILICA PHASES, COSTA RICA RIFT, DEEP SEA DRILLING PROJECT LEG $69^{1}$
}

\author{
James R. Hein, U.S. Geological Survey, 345 Middlefield Road, Menlo Park, California \\ and \\ Hsueh-Wen Yeh, Hawaii Institute of Geophysics, University of Hawaii, Honolulu, Hawaii
}

\begin{abstract}
Seven opal-CT-rich and five quartz-rich porcellanites and cherts from Site 504 have a range in oxygen-isotope values of 24.4 and $29.4 \%$. In opal-CT rocks, $\delta^{18} \mathrm{O}$ becomes larger with sub-bottom depth and with age. Quartz-rich rocks do not show these trends. Boron, in general, increases with decreasing $\delta^{18} \mathrm{O}$ for porcellanites and cherts considered together, supporting the conclusion that boron is incorporated within the quartz crystal structure during precipitation of the $\mathrm{SiO}_{2}$. Silicification of the chalks at Site 504 began $1 \mathrm{~m} . \mathrm{y}$. ago-that is, $5 \mathrm{~m}$.y. after sedimentation commenced on the oceanic crust. Temperatures of chert formation determined from oxygen-isotope compositions reflect diagenetic temperatures rather than bottom-water temperatures, and are comparable to temperatures of formation determined by down-hole measurements. Opal-A in the chalks began conversion to opal-CT when a temperature of $50^{\circ} \mathrm{C}$ was reached in the sediment column. Conversion of opal-CT to quartz started at $55^{\circ} \mathrm{C}$. Silicification occurred over a stratigraphic thickness of about 10 meters when the temperature at the top of the 10 meters reached about $50^{\circ} \mathrm{C}$. It took about 250,000 years to complete the silica transformation within each 10-meter interval of sediment at Site 504. Quartz formed over a stratigraphic range of at least 30 meters, at temperatures of about 54 to $60^{\circ} \mathrm{C}$. The time and temperatures of silicification of Site 504 rocks are more like those at continental margins than those in deep-sea, open-ocean deposits.
\end{abstract}

\section{INTRODUCTION}

We determined the oxygen-isotope composition of 12 siliceous rocks cored at Site 504 during Leg 69 of the Deep Sea Drilling Project (Fig. 1). Analyzed rocks include seven opal-CT-rich and five quartz-rich porcellanites and cherts from Holes 504, 504A, and 504B (Table 1). The holes are placed in a nearly east-west line; Hole 504A is 67.3 meters west of Hole 504, and Hole 504B is about 220 meters east of Hole 504. We discuss the isotopic compositions in relation to temperatures of formation, chemical and mineralogic compositions, and silica-water fractionation factors. Temperatures of formation are determined by using both Knauth and Epstein's (1976) empirically derived and Clayton et al.'s (1972) experimentally derived $\mathrm{SiO}_{2}$-water fractionation factors, and are compared with temperatures derived from down-hole measurements (Becker et al., this volume). The rocks analyzed here are a subset of the 21 siliceous rocks described by Hein et al. (this volume), who present detailed petrographic, mineralogic, and chemical data.

Sediment at Site 504 is made up of 264 to 274.5 meters of siliceous nannofossil ooze, chalk, and limestone that rest on basaltic basement that is $6.2 \mathrm{~m}$.y. old, as determined from magnetic anomalies (Fig. 2). Samples analyzed for their oxygen-isotope compositions occur in upper Miocene chalk and limestone at sub-bottom depths of 227 to 262 meters (Table 2). Silicified rocks span a range in age of only about $1 \mathrm{~m}$.y., that is, they occur in sediments deposited 5.2 to $6.2 \mathrm{~m}$.y. ago.

\footnotetext{
${ }^{1}$ Cann, J. R., Langseth, M. G., Honnorez, J., Von Herzen, R. P., White, S. M., et al., Init. Repts. DSDP, 69: Washington (U.S. Govt. Printing Office).
}

The porcellanites and cherts are cemented and replaced carbonates and commonly contain some included calcite. Chert and limestone occur only below 225 meters. Siliceous rocks make up less than $15 \%$ of the lowermost 40 meters of recovered section.

\section{METHODS}

The fluorination method of Taylor and Epstein (1962) was used to extract oxygen from the siliceous rocks for determination of $18 \mathrm{O} / 16 \mathrm{O}$ ratios. Samples were quantitatively converted to $\mathrm{CO}_{2}$ and isotopically analyzed with a dual-collector mass spectrometer. Results are reported as $\delta^{18} \mathrm{O}_{\text {SMOw }}$ values that are the per mil deviation of the ${ }^{18} \mathrm{O} / 16 \mathrm{O}$ ratio of a sample from that of Standard Mean Ocean Water (Craig, 1961). Two extractions and two ${ }^{18} \mathrm{O} / 16 \mathrm{O}$ determinations were made on some samples to check analytical precision.

Siliceous rocks were pretreated before isotopic analysis: (1) Carbonate minerals were removed with dilute $\mathrm{HCl}(10 \%$ by volume); the treatment was carried out at room temperature and has no effect on the $\delta^{18} \mathrm{O}_{\mathrm{SMOW}}$ of the chert (Yeh and Epstein, in prep.). (2) The absorbed and other loosely bound waters were removed from the chert prior to fluorination by heating the samples at about $250^{\circ} \mathrm{C}$ under high vacuum. After dehydration, samples were loaded into $\mathrm{Ni}$ reaction vessels under zero-humidity atmosphere.

Coexisting opal-CT and quartz were not separated before isotopic analysis. Values of $\delta^{18} \mathrm{O}$ for these samples (Table 1) are probably higher than they would be if the quartz were isolated and analyzed separately, if Knauth and Epstein's (1975) and Pisciotto's (1978) observations are applicable to our samples. Major, minor, and trace elements of the cherts analyzed for their oxygen-isotope compositions are presented by Hein et al. (this volume).

\section{RESULTS}

$\delta^{18} \mathrm{O}$ values range from 24.4 to $29.4 \%$ for all analyzed rocks; $\delta^{18} \mathrm{O}$ values average $24.6 \%$ (S.D. $=0.25$ ) for the two pure quartz rocks, $25.6 \%$ (S.D. $=0.72$ ) for the three quartz-rich rocks, and $27.4 \%$ (S.D. $=1.17$ ) for the opal-CT-rich rocks (Table 1). These values fall near and below the lower end of the range of values (27.1- 


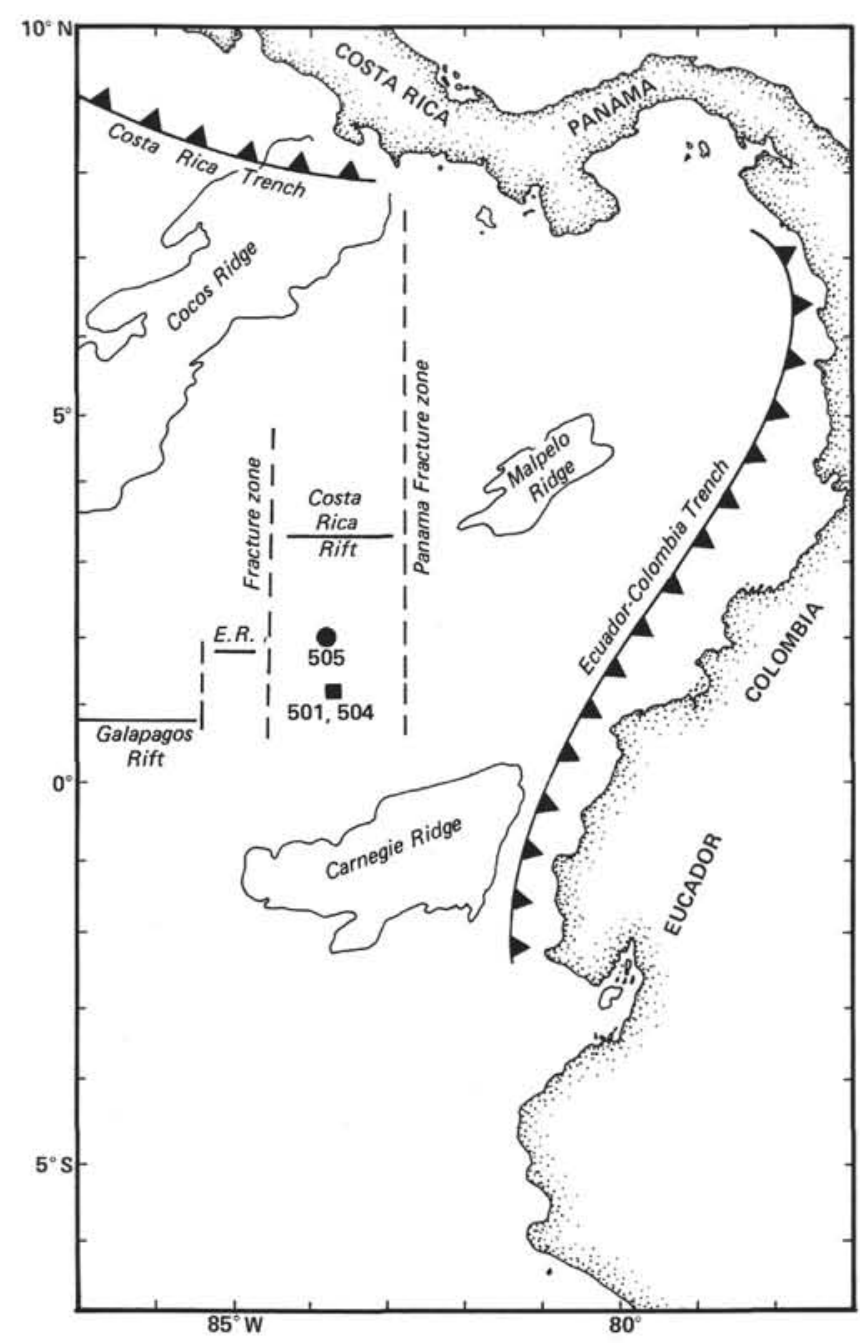

Figure 1. Location of DSDP Leg 69 Sites 504 and 505 and Leg 68 Site 501 , located 200 meters from Site 504. Silicified rocks were cored only at Site 504 during Leg 69.

$41.8 \%$ ) reported for other marine cherts and porcellanites (Knauth and Epstein, 1975; Levitan et al., 1975; Kolodny and Epstein, 1976; Kastner, 1976; Hein and Yeh, 1981). Our $\delta^{18} \mathrm{O}$ values, however, are comparable to those obtained from siliceous rocks from the Miocene Monterey Formation of California (Murata et al., 1977; Pisciotto, 1978). Opal-CT rocks show a poorly defined trend of larger $\delta^{18} \mathrm{O}$ values with sub-bottom depth; quartz rocks show no pattern (Fig. 3B). Similarly, $\delta^{18} \mathrm{O}$ may increase with increasing age of the enclosing sediment for opal-CT, but not for quartz-rich rocks (Fig. $3 \mathrm{C}$ ). $\delta^{18} \mathrm{O}$ shows a marked increase from about 5.3 to 5.9 m.y. ago, and then a sharp decrease to 6.0 m.y. ago. Additional analyses may significantly change this pattern. Also, the timing of this trend is only apparent because the ages of the cherts are not the same as the ages of the enclosing sediments; the youngest cherts probably are forming now, whereas the oldest may have formed a million years ago (see discussion section). Because chert probably did not form until $5 \mathrm{~m}$.y. after deposition of the host sediment, the time scale of formation should be translated $5 \mathrm{~m}$.y. toward the present to place the $\delta^{18} \mathrm{O}$ changes into a more meaningful temporal frame.

\section{$\delta^{18} \mathrm{O}$ and Silica Phases}

On the average, $\delta^{18} \mathrm{O}$ values increase slightly from pure quartz to quartz-rich to opal-CT rocks, but no consistent trend is seen between $\delta^{18} \mathrm{O}$ values and quartz/ opal-CT $\times 8$ ratios, or with opal-CT crystallite sizes. With the exception of one sample, opal-CT $d$-spacings may show a poorly defined tendency to decrease with decreasing $\delta^{18} \mathrm{O}$ values (Fig. 3A). If the apparently anomalous value is real, however, no trend would exist. Certainly, if the $d(101)$ spacings for opal-CT in rocks also rich in quartz are omitted, then no trend would exist. Murata et al. (1977) found that $\delta^{18} \mathrm{O}$ values remained constant as $d(101)$ spacings in porcellanites decreased with depth in the Monterey Formation (see also Pisciotto, 1978).

Although there are only a few measurements, quartz crystallinity may increase with decreasing $\delta^{18} \mathrm{O}$ values (Fig. 4). Quartz crystallinity was measured according to the technique of Murata and Norman (1976), and is based on a scale of 10 , plutonic quartz (high crystallinity) defining the high end, and diagenetic quartz (poor crystallinity) defining the low end. A decrease in $\delta^{18} \mathrm{O}$ with increasing crystallinity of quartz was noted in earlier studies (Pisciotto, 1978; Hein and Yeh, 1981).

\section{$\delta^{18} \mathrm{O}$ and Chemical Composition of Chert}

Quartz cherts and porcellanites are chemically pure, averaging 98.1 and $97.5 \% \mathrm{SiO}_{2}+$ volatiles, respectively (Hein et al., this volume). Comparisons between the chemistry (Hein et al., this volume) and the $\delta^{18} \mathrm{O}$ values of silicified rocks reveal only one well-defined trend. Boron, in general, increases with decreasing $\delta^{18} \mathrm{O}$ for porcellanites and cherts considered together. This trend supports the conclusion that boron is incorporated within the quartz crystal structure during precipitation of the $\mathrm{SiO}_{2}$ (Hein et al., 1981; Hein et al., this volume). This same boron- $\delta^{18} \mathrm{O}$ relation was noted for Leg 62 cherts (Hein and Yeh, 1981).

\section{DISCUSSION}

\section{Temperature of Formation}

Possible temperatures of formation of secondary silica recovered at Site 504 were determined from the equations of Knauth and Epstein (1976) and Clayton et al. (1972), assuming first $0.0 \%_{0}$ and second $-4.2 \%_{0}$ for the waters of formation (Table 2; Fig. 5). The $-4.2 \%$ value is the measured $\delta^{18} \mathrm{O}$ from pore water recovered near the base of the sediment section at Site 504 (Mottl, Lawrence, et al., this volume). The four sets of temperatures derived from these calculations span a wide range, 18 to $75^{\circ} \mathrm{C}$ (Table 2; Fig. 5). Knauth and Epstein's fractionation factor yields lower temperatures of formation for each assumed pore-water composition. The temperatures at the sub-bottom depth where cherts occur now, and where they were $1 \mathrm{~m} . \mathrm{y}$. ago, are always greater than temperatures determined from Knauth and Epstein's equation, assuming $-4.2 \%$ for the water, but they span the other three temperature curves derived from the isotopic data. The actual $\delta^{18} \mathrm{O}$ of the water(s) from which cherts formed is most likely between 0 and $-4.2 \%$. The 
Table 1. $\delta^{18}$ OSMOW values, lithologies, and mineralogy of DSDP Leg 69 silicified rocks.

\begin{tabular}{|c|c|c|c|c|c|c|c|}
\hline \multirow[b]{2}{*}{ Sample } & \multirow[b]{2}{*}{ Lithology } & \multicolumn{4}{|c|}{ X-Ray Mineralogy } & \multirow{2}{*}{$\begin{array}{c}\text { Quartz/ } \\
\text { Opal-CT × } 8\end{array}$} & \multirow[b]{2}{*}{$\delta^{18} \mathrm{OSMOW}_{\mathrm{SMO}}$} \\
\hline & & Major & Moderate & Minor & Trace & & \\
\hline $504-53-1,10 \mathrm{~cm}$ & $\begin{array}{l}\text { Greenish-tan calcareous } \\
\text { opal-CT chert }\end{array}$ & $\begin{array}{l}\text { Calcite, }^{\mathrm{a}} \\
\text { opal-CT }\end{array}$ & - & Quartz & - & 0.02 & 26.8 \\
\hline $504 \mathrm{~A}-1, \mathrm{CC}(\mathrm{I})$ & $\begin{array}{l}\text { Greenish-tan calcareous } \\
\text { porcellanite }\end{array}$ & Calcite & $\begin{array}{l}\text { Quartz, } \\
\text { opal-CT }\end{array}$ & - & - & 0.06 & 26.0 \\
\hline $504 \mathrm{~A}-2, \mathrm{CC}$ & $\begin{array}{l}\text { Gray calcareous } \\
\text { porcellanite }\end{array}$ & $\begin{array}{l}\text { Calcite, } \\
\text { opal-CT }\end{array}$ & - & Quartz & - & 0.03 & 26.3 \\
\hline $504 \mathrm{~A}-3-1,59 \mathrm{~cm}$ & $\begin{array}{l}\text { Greenish-tan calcareous } \\
\text { chert and porcellanite }\end{array}$ & Quartz & $\begin{array}{r}\text { Opal-CT, } \\
\text { calcite }\end{array}$ & - & - & 0.22 & $26.1^{\mathrm{b}}$ \\
\hline $504 \mathrm{~A}-3-1,103 \mathrm{~cm}$ & Gray-brown chert & Quartz & - & Opal-CT & Calcite & 0.22 & 24.8 \\
\hline $504 \mathrm{~A}-4-1,81 \mathrm{~cm}$ & $\begin{array}{l}\text { Gray-brown calcareous } \\
\text { porcellanite }\end{array}$ & $\begin{array}{l}\text { Calcite, } \\
\text { opal-CT }\end{array}$ & - & Quartz & - & 0.02 & 27.2 \\
\hline $504 \mathrm{~A}-5-1,37 \mathrm{~cm}$ & Dark-brown chert & Quartz & - & - & Calcite & - & 24.8 \\
\hline $504 \mathrm{~A}-5-1,75 \mathrm{~cm}$ & $\begin{array}{l}\text { Gray calcareous } \\
\text { porcellanite }\end{array}$ & $\begin{array}{l}\text { Calcite, } \\
\text { opal-CT }\end{array}$ & Quartz & - & - & 0.05 & 28.1 \\
\hline $504 \mathrm{~A}-5-1,75 \mathrm{~cm}$ & Gray-brown chert & Quartz & Opal-CT & - & Calcite & 0.19 & 26.0 \\
\hline $504 \mathrm{~A}-5-1,75 \mathrm{~cm}$ & Dark-brown chert & Quartz & - & - & - & - & 24.4 \\
\hline $504 \mathrm{~B}-1-1,63 \mathrm{~cm}$ & $\begin{array}{l}\text { Gray-brown calcareous } \\
\text { porcellanite }\end{array}$ & $\begin{array}{l}\text { Calcite, } \\
\text { opal-CT }\end{array}$ & - & - & Quartz & 0.01 & 29.4 \\
\hline $504 \mathrm{~B}-1-1,63 \mathrm{~cm}$ & $\begin{array}{l}\text { Calcareous porcellanite } \\
\text { and chert }\end{array}$ & Opal-CT & $\begin{array}{l}\text { Calcite, } \\
\text { quartz }\end{array}$ & - & - & 0.04 & $27.8^{\mathrm{b}}$ \\
\hline
\end{tabular}

a Calcite removed from all samples before isotopic analysis.

$\mathrm{b}$ Value may be in error because of nitrogen leak during analysis.

range of possible temperatures of formation of the cherts is bracketed by the present in situ temperature of each chert $\left(T_{5}\right.$, Fig. 5) and its in situ temperature 1 m.y. ago $\left(T_{6}\right.$, Fig. 5), when silicification started (Table 2; Fig. $5)$. The range of possible temperatures of formation, bracketed by $T_{5}$ and $T_{6}$ in Figure 5 (shaded area), falls between the temperature curves derived from isotopic compositions, which supports the notion that the actual $\delta^{18} \mathrm{O}$ values of the waters of formation are between 0 and $-4.2 \%$.

The temperature in the sediment column where the youngest secondary silica occurs is $50^{\circ} \mathrm{C}$ (not shown on Table 2), a temperature identical to that experienced by the oldest (most deeply buried) chert $1 \mathrm{~m} . \mathrm{y}$. ago when silicification began. Only the second temperature from $T_{5}$ (Table 2) and the last six temperatures from $T_{6}$ (Table 2) represent temperatures of transformation of opal-A to opal-CT. The temperature of transformation for the other rocks, also $50^{\circ} \mathrm{C}$, falls between the higher values of $T_{5}$ and the lower values of $T_{6}$; the $50^{\circ} \mathrm{C}$ temperature approaches $T_{5}$ for younger cherts, and $T_{6}$ for older ones. In other words, 1 m.y. ago $\left(T_{6}\right)$ the lowest samples reached $50^{\circ} \mathrm{C}$, the temperature for opal-A $\rightarrow$ opal-CT. Shallower samples (strata) were still too cool for the polymorph transformation. Today $\left(T_{5}\right)$, the lowest strata are hot enough for opal-CT $\rightarrow$ quartz, while the shallowest samples $(225 \mathrm{~m})$ are just reaching a temperature appropriate for opal-A $\rightarrow$ opal-CT. This suggests that silicification occurs in intervals, probably of several meters, where opal-A is transformed to opal-CT at $50^{\circ} \mathrm{C}$.

We can estimate the interval of silicification as $10 \mathrm{me}$ ters. Ten meters is the stratigraphic thickness from the first minor occurrence of secondary silica, where the surrounding chalk contains much opal-A $(225 \mathrm{~m})$, to the first occurrence of abundant secondary silica, where the surrounding chalk has lost all opal-A to the chert (235 m). It follows then that silicification moved gradually upward in the lowermost 40 meters of section in the time interval of $1 \mathrm{~m} . \mathrm{y}$. , that is, from the present back in time to $1 \mathrm{~m}$.y. ago when silicification started, silicification within each 10-meter interval becoming complete in about 250,000 years. Silicification is currently occurring between 30 and 40 meters above basalts, and presumably all the opal-A within this interval will be transformed into opal-CT within the next 250,000 years. The sharp boundary between the silicified sedimentary rocks and opal-A-containing chalk at Site 504 and the absence of appreciable corrosion of diatoms in chalk require that the temperature of transformation of opal-A to opal-CT was narrow and consistent, or that silicification occurred over certain stratigraphic intervals instantaneously, or both. The stratigraphic intervals should be defined by rates of sedimentation and heat flow. We believe that both of these processes operated during silicification of Leg 69 rocks; the temperature of transformation was $50 \pm 2{ }^{\circ} \mathrm{C}$, and the interval of silicification was about $10 \pm 3$ meters, allowing for poor core recovery.

The initial temperature of transformation of opal-CT to quartz is also tightly constrained at about $55 \pm 2{ }^{\circ} \mathrm{C}$ for Leg 69 rocks. Quartz is common at temperatures greater than 57 or $58^{\circ} \mathrm{C}$. The transformation of opal-CT to quartz probably occurs over relatively thick stratigraphic intervals and for long periods of time. Quartz no doubt is forming over a stratigraphic range of at least 30 meters, at temperatures of about 54 to $60^{\circ} \mathrm{C}$.

The initiation of silicification at $50^{\circ} \mathrm{C}$ probably depended on porosity, type and abundance of siliceous microfossils in the host chalk, pore-water chemistry, and geothermal gradient. The initiation of quartz formation probably depended on the degree of ordering of the opalCT, pore-water chemistry, and geothermal gradient. 


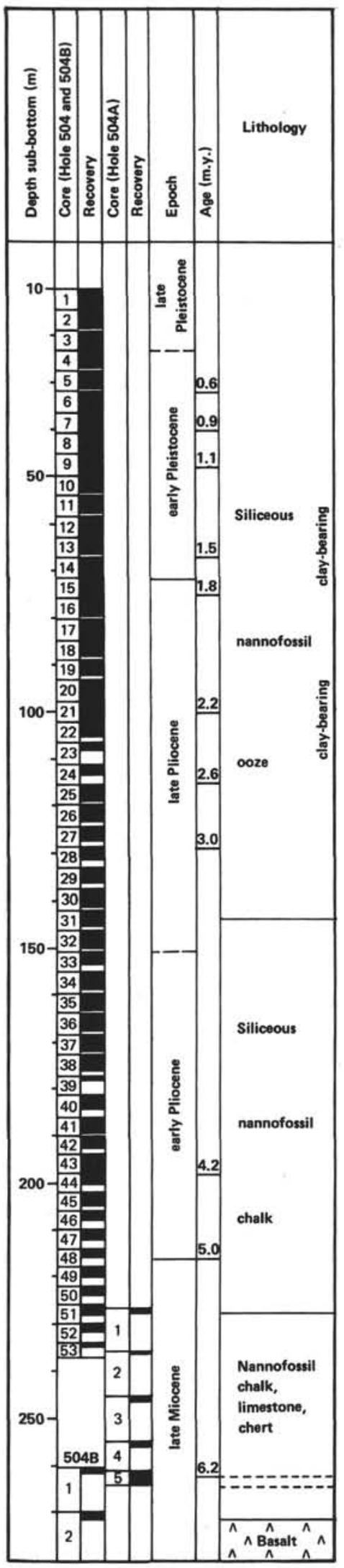

Figure 2. General lithologies, ages, and stratigraphic locations of siliceous rocks studied from DSDP Leg 69 . See Table 1 of this paper and table 1 of Hein et al. (this volume) for a description of each studied rock.
Uncertainty in pore-water $\delta^{18} \mathrm{O}$ is probably the main cause of the lack of correspondence between actual and isotopically derived temperatures of silicification. In addition, it is likely that neither Clayton et al.'s (1972) nor Knauth and Epstein's (1975) temperature scales describe the precise relation between $\delta^{18} \mathrm{O}$ and formation temperatures of chert. A further complication when considering $\delta^{18} \mathrm{O}$ and temperatures of formation of cherts is that older (for example, Cretaceous), bedded quartz cherts may record the general or smoothed temperature of their diagenetic environment-the environment of quartz recrystallization, rather than the environment of initial silicification. Thus, temperature curves may record only environments that existed during advanced silicification (see also Lawrence et al., 1979).

\section{Paleoclimates versus Diagenetic Environments}

Debate has been vigorous as to whether $\delta^{18} \mathrm{O}$ values of marine cherts primarily reflect paleoclimates (bottom-water temperatures), or diagenetic environments (Degens and Epstein, 1962; Kolodny and Epstein, 1976; Knauth and Epstein, 1975). Leg 69 isotopic data show that for rocks in the early stages of silicification in areas of high heat flow paleoclimates are not reflected by the isotopic compositions of cherts. The bottom-water temperature above Site 504 is about 2 to $3^{\circ} \mathrm{C}$. Knauth and Epstein (1975) suggested that opal-CT-rich rocks may reflect bottom-water temperatures more than quartz cherts do. Although Leg 69 opal-CT-rich rocks do produce lower temperature values than quartz rocks, the temperatures definitely do not record paleoclimates or bottom- or surface-water temperatures (see Keigwin and Lawrence, this volume). For Cretaceous rocks recovered during Leg 62, an opal-CT-derived temperature did plot closer to Douglas and Savin's (1973) bottom-water temperature curve than did other samples of the same age (Hein and Yeh, 1981).

In view of the uncertainty in the precise $\delta^{18} \mathrm{O}$ of the water of formation, and the imperfections in the temperature scales used, the isotopically derived temperature of formation of chert is consistent with the temperature of formation (the sub-bottom temperature) measured in the sediment column. Thus, the isotopic composition of the cherts reflects the diagenetic temperatures of formation, rather than paleoclimates.

Several aspects set Leg 69 silicified rocks apart from those analyzed in previous studies, and may help us to understand what diagenetic stage the isotopic compositions actually reflect. Leg 69 rocks are younger, formed under the influence of higher heat flow, and are not as diagenetically advanced as cherts analyzed previously. Chert analyzed in previous studies recorded the last, most-advanced diagenetic stage-where quartz chert recrystallized, or where opal-CT was more ordered. Evidence suggests that oxygen isotopes re-equilibrated during quartz recrystallization in deep-sea cherts (Hein and Yeh, 1981).

\section{Comparison with Continental-Margin Siliceous Rocks}

Hein et al. (1978) suggested that opal-A transforms into opal-CT faster and at higher temperatures in con- 
Table 2. Determination of temperature and depth of formation of DSDP Leg 69 siliceous rocks.

\begin{tabular}{|c|c|c|c|c|c|c|c|c|}
\hline Sample & $\begin{array}{l}\text { Sub-bottom } \\
\text { Depth of } \\
\text { Cherts } \\
\text { (m) }\end{array}$ & $\begin{array}{l}\text { Age of } \\
\text { Enclosing } \\
\text { Sediment } \\
\text { (m.y.) }\end{array}$ & $\begin{array}{c}\delta^{18} \mathrm{O} \\
\text { Temperature } \\
\text { of Formation: } \\
\mathrm{T}_{1}{ }^{b} \\
\left({ }^{\circ} \mathrm{C}\right)\end{array}$ & $\begin{array}{c}\delta^{18} \mathrm{O} \\
\text { Temperature } \\
\text { of Formation: } \\
\mathrm{T}_{2}{ }^{\mathrm{C}} \\
\left({ }^{\circ} \mathrm{C}\right)\end{array}$ & $\begin{array}{c}\delta^{18} \mathrm{O} \\
\text { Temperature } \\
\text { of Formation: } \\
\mathrm{T}_{3} \mathrm{~d} \\
\left({ }^{\circ} \mathrm{C}\right)\end{array}$ & $\begin{array}{c}\delta^{18} \mathrm{O} \\
\text { Temperature } \\
\text { of Formation: } \\
\mathrm{T}_{4}{ }^{\mathrm{e}} \\
\left({ }^{\circ} \mathrm{C}\right)\end{array}$ & $\begin{array}{c}\text { Present } \\
\text { in situ } \\
\text { Measured } \\
\text { Temperature: } \\
\mathrm{T}_{5} \mathrm{f} \\
\left({ }^{\circ} \mathrm{C}\right)\end{array}$ & $\begin{array}{c}\text { Temperature at } \\
\text { Place of Chert } \\
1 \text { m.y. Ago: } \\
\text { T } 6 \\
\left({ }^{\circ} \mathrm{C}\right)\end{array}$ \\
\hline $504-53-1,10 \mathrm{~cm}$ & 234.1 & $\sim 5.5$ & 63 & 42 & 49 & 29 & 52.7 & 43 \\
\hline $504 \mathrm{~A}-1, \mathrm{CC}(\mathrm{I})$ & 227.0 & $\sim 5.3$ & 68 & 46 & 54 & 32 & 51.1 & 42 \\
\hline $504 \mathrm{~A}-2, \mathrm{CC}$ & 236.0 & $\sim 5.5$ & 66 & 44 & 52 & 31 & 53.1 & 44 \\
\hline $504 \mathrm{~A}-3-1,59 \mathrm{~cm}$ & 246.1 & $\sim 5.8$ & 67 & 45 & 53 & 32 & 55.4 & 46 \\
\hline $504 \mathrm{~A}-3-1,103 \mathrm{~cm}$ & 246.5 & $\sim 5.8$ & 75 & 51 & 60 & 38 & 55.5 & 46 \\
\hline $504 \mathrm{~A}-4-1,81 \mathrm{~cm}$ & 255.8 & $\sim 6.0$ & 61 & 40 & 47 & 27 & 57.6 & 48 \\
\hline $504 \mathrm{~A}-5-1,37 \mathrm{~cm}$ & 261.4 & $\sim 6.1$ & 75 & 51 & 60 & 38 & 58.8 & 50 \\
\hline $504 \mathrm{~A}-5-1,75 \mathrm{~cm}$ & 261.8 & $\sim 6.2$ & 57 & 36 & 43 & 23 & 58.9 & 50 \\
\hline $504 \mathrm{~A}-5-1,75 \mathrm{~cm}$ & 261.8 & $\sim 6.2$ & 68 & 45 & 54 & 32 & 58.9 & 50 \\
\hline $504 \mathrm{~A}-5-1,75 \mathrm{~cm}$ & 261.8 & $\sim 6.2$ & 77 & 53 & 63 & 40 & 58.9 & 50 \\
\hline $504 \mathrm{~B}-1-1,63 \mathrm{~cm}$ & 261.0 & $\sim 5.9$ & 50 & 31 & 36 & 18 & 58.7 & 50 \\
\hline $504 \mathrm{~B}-1-1,63 \mathrm{~cm}$ & 261.0 & $\sim 5.9$ & 58 & 38 & 44 & 24 & 58.7 & 50 \\
\hline
\end{tabular}

a Age estimated from last diatom datum at 215 meters, 5 m.y. (Sancetta, this volume), extrapolated to a basement age of 6.2 m.y.

b Calculated from Clayton et al. (1972), assuming $0.0 \%$ for water.

c Calculated from Clayton et al. (1972), assuming $-4.2 \%$ for water (Mottl, Lawrence, et al., this volume).

d Calculated from Knauth and Epstein (1975), assuming 0.0\% for water.

e Calculated from Knauth and Epstein (1975), assuming $-4.2 \%$ for water.

In situ measurements at depth where rocks were collected.

$g$ Temperatures the rocks were subjected to 1 m.y. ago.
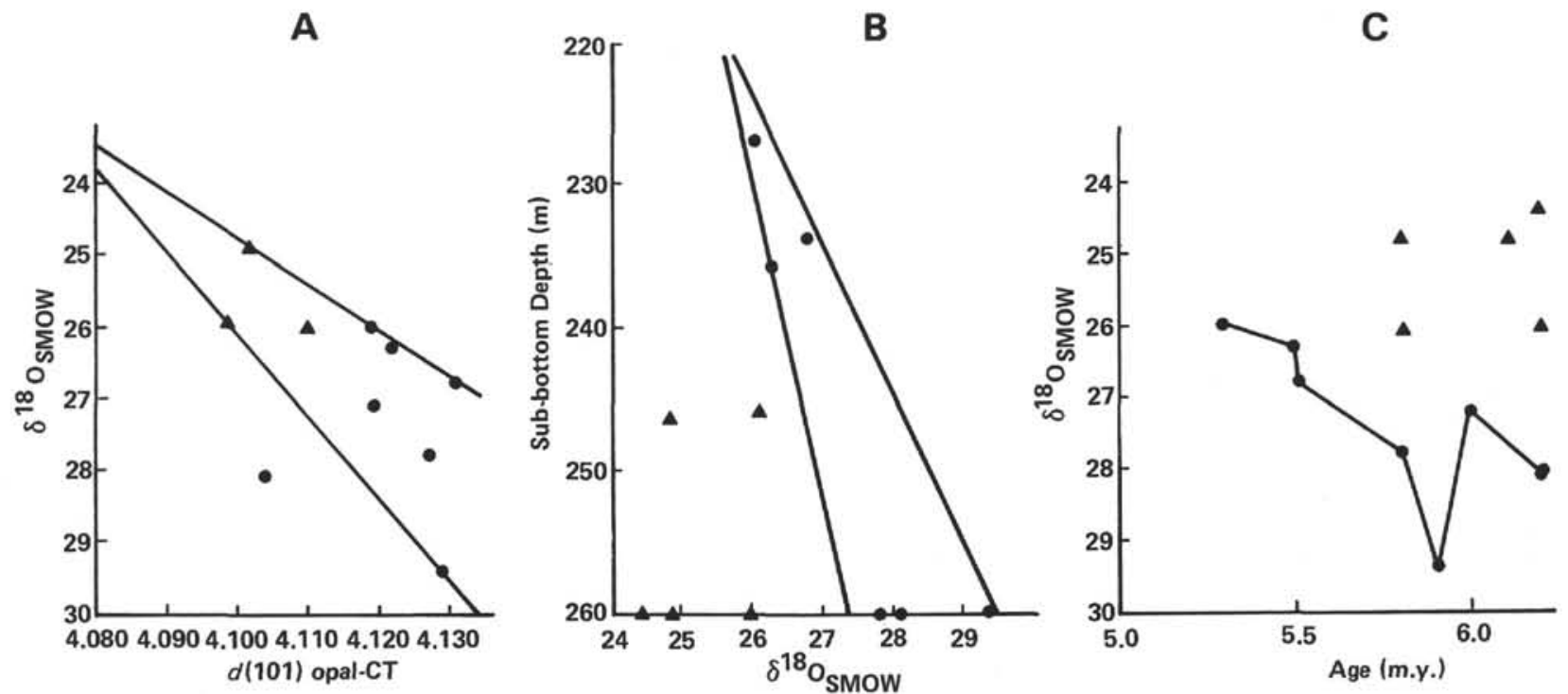

Figure 3. $\delta^{18} \mathrm{O}$ compositions versus (A) opal-CT $d(101)$ spacings, (B) sub-bottom depths, and (C) ages of Leg 69 siliceous rocks. $\delta^{18} \mathrm{O}$ quartz-rich rocks, indicated by triangles, show no relation to age or sub-bottom depth of occurrence. Lines suggest possible but poorly defined trends of increasing $\delta^{18} \mathrm{O}$ with sub-bottom depth of porcellanites, and decreasing $\delta^{18} \mathrm{O}$ with decreasing opal-CT $d$-spacings. Solid dots are opal-CT-rich rocks.

tinental-margin deposits than in deep-sea, open-ocean deposits. Continental-margin deposits are characterized by high rates of sedimentation, and temperature is a dominant control in the transformation of silica, whereas in the open-ocean environment, where rates of sedimentation are generally very low, time plays an increasingly important role relative to temperature (see fig. 5 of Hein et al., this volume; Pisciotto, 1978). In both environments, the chemistry of the host sediments and pore waters also influences silica transformations (Kastner et al., 1977; Knauth, 1979). The transformation of opal-CT to quartz and the maturation of quartz in open- ocean cherts likewise may occur slower and at lower temperatures than the same transformation in continental-margin deposits. This relationship can be illustrated by comparing $\delta^{18} \mathrm{O}$ values and quartz-crystallinity values of Leg 62 cherts (open-ocean deposits) with those of siliceous rocks in the Monterey Formation of California (Fig. 4; Pisciotto, 1978); the curve for the Monterey Formation falls below (lighter $\delta^{18} \mathrm{O}$, greater temperatures) that of Leg 62 cherts, suggesting higher temperatures of formation (Fig. 4). The curve for Leg 69 rocks falls slightly below that of the Monterey Formation, suggesting equivalent or even higher temperatures of 


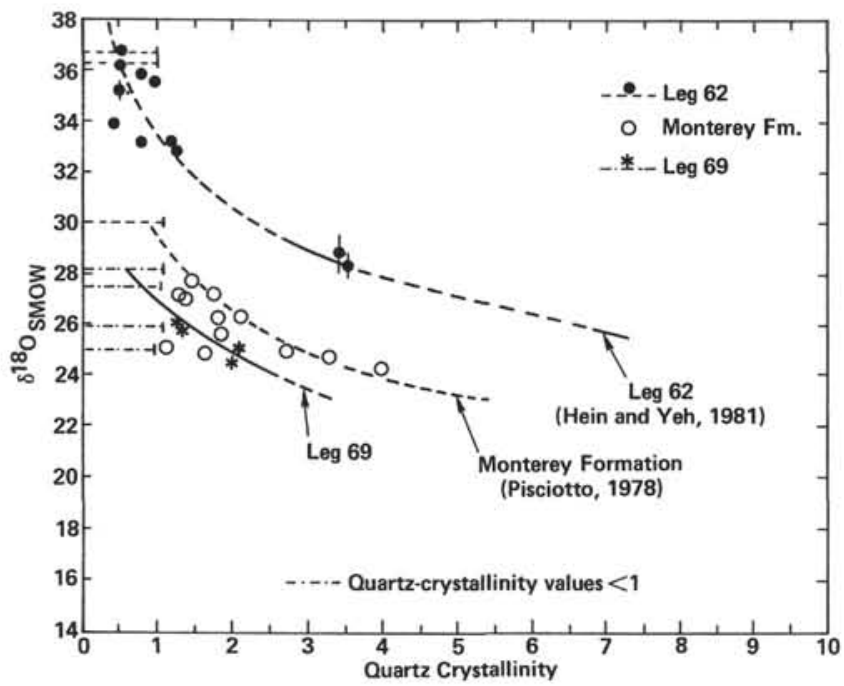

Figure 4. $\delta^{18} \mathrm{O}$ compositions versus the crystallinity of quartz in Leg 69 silicified rocks, cherts and porcellanites from the Monterey Formation of California, and DSDP Leg 62 rocks. This figure is from Hein and Yeh (1981), with the addition of Leg 69 data.

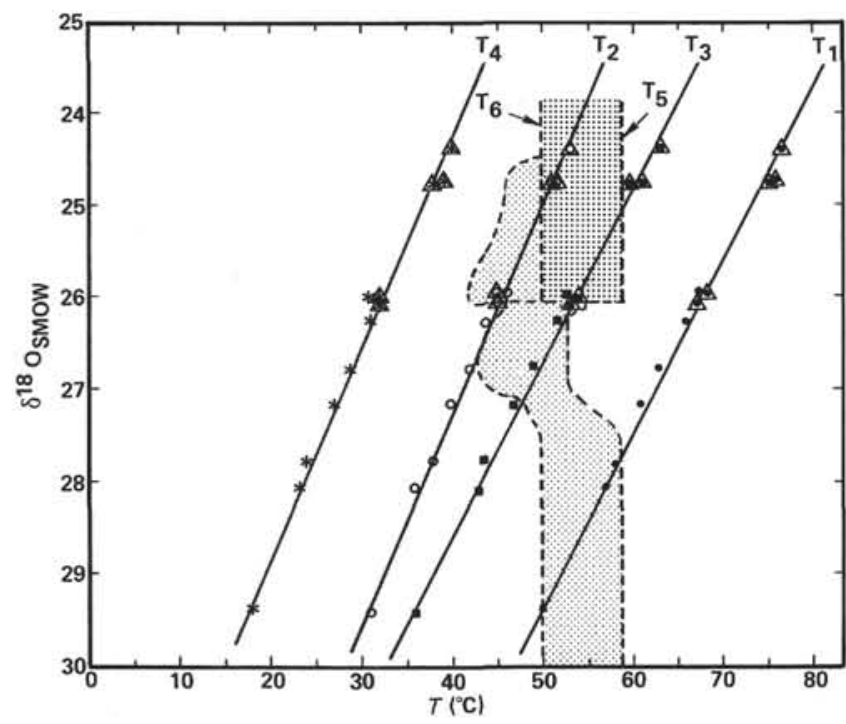

Figure 5. $\delta^{18} \mathrm{O}$ compositions versus possible temperatures of formation of Leg 69 cherts (see Table 2); $T_{1}$ and $T_{2}$ represent temperatures derived from Clayton et al.'s (1972) silica-water fractionation factor, assuming 0.0 and $-4.2 \%$ for waters of reaction, respectively. $T_{3}$ and $T_{4}$ are temperatures derived from the equation of Knauth and Epstein (1976), assuming the same two values for water. The interval between $T_{5}$ and $T_{6}$ spans the upper and lower limits of the possible temperatures of formation of each sample, as determined by downhole temperature measurements (see text). Two samples with the same $\delta^{18} \mathrm{O}$ and different temperatures of formation cause the overlap in the patterned area. Triangles represent quartz-rich rocks, the other symbols opal-CT-rich rocks.

formation. In this way Leg 69 rocks are more similar to continental-margin deposits than open-ocean ones (compare Fig. 5 with fig. 5 of Hein et al., this volume).

\section{SUMMARY AND CONCLUSIONS}

$\delta^{18} \mathrm{O}$ values for Leg 69 opal-CT and quartz rocks range from 24.4 to $29.4 \%$, values comparable to those of continental-margin rocks of the Monterey Formation of California. Poorly defined trends show decreasing $\delta^{18} \mathrm{O}$ with increasing opal-CT $d$-spacings, and increasing $\delta^{18} \mathrm{O}$ with increasing depth and age of enclosing sediment. An additional trend shows increasing boron content of cherts with decreasing $\delta^{18} \mathrm{O}$. This boron- $\delta^{18} \mathrm{O}$ relation reflects the substitution of boron into secondary quartz as it precipitates from solution.

Temperatures of chert formation, as determined from the oxygen-isotope compositions, reflect diagenetic temperatures rather than bottom-water temperatures, and are comparable to temperatures of formation determined by down-hole measurements. The lack of exact correspondence between isotopically determined and actual temperatures of formation results from (1) lack of a silica-water fractionation factor applicable to low-temperature opal-CT-quartz rocks, and (2) not knowing the precise $\delta^{18} \mathrm{O}$ of waters of formation.

The transformation of opal-A to opal-CT occurred at $50 \pm 2{ }^{\circ} \mathrm{C}$, and that of opal-CT to quartz at $55 \pm 2{ }^{\circ} \mathrm{C}$. Silicification probably occurred over about 10 -meter stratigraphic intervals. That is, once a temperature of $50^{\circ} \mathrm{C}$ was reached at any level above the basalts, the opal-A in the overlying 10-meter stratigraphic interval took about 250,000 years to convert to opal-CT as the $50^{\circ}$ isotherm rose to the top of the interval. The next 10 -meter interval was silicified in the following 250,000 years. The current 10-meter interval of silicification is between 225 and 235 meters sub-bottom, that is, 30 to 40 meters above basalts. On the other hand, quartz formed over wide stratigraphic intervals for relatively long periods of time.

The time and temperatures of silicification of Leg 69 rocks are more like those of continental margins than those of deep-sea, open-ocean deposits.

\section{ACKNOWLEDGMENTS}

We appreciate technical and analytical help from Lisa Morgenson, Marla Wilson, and Rosemary Sliney, U.S. Geological Survey, and Chung-Ho Wang and Rita Pujalet, Hawaii Institute of Geophysics. J. R. Lawrence and Constance Sancetta, both at Lamont-Doherty Geological Observatory, and T. L. Vallier, U.S. Geological Survey, provided critical reviews. Research was completed in conjunction with I.G.C.P. Project 115, Siliceous Deposits of the Pacific Region. Hawaii Institute of Geophysics Contribution No. 1119.

\section{NOTE ADDED IN PROOF}

Work subsequent to the completion of this chapter indicates basement age to be 5.9 instead of 6.2 m.y.

\section{REFERENCES}

Clayton, R. N., O'Neil, J. R., and Mayeda, T. K., 1972. Oxygen isotope exchange between quartz and water. J. Geophys. Res., 77:3057-3067.

Craig, H., 1961. Standards for reporting concentrations of deuterium and oxygen-18 in natural waters. Science, 133:1833-1834.

Degens, E. T., and Epstein, S., 1962. Relation between $\mathrm{O}^{18} / \mathrm{O}^{16}$ ratios in coexisting carbonates, cherts, and diatomites. Bull. Am. Assoc. Petrol. Geol., 46:534-542.

Douglas, R. G., and Savin, S. M., 1973. Oxygen and carbon isotope analyses of Cretaceous and Tertiary foraminifera from the central North Pacific. In Winterer, E. L., Ewing, J. I., et al., Init. Repts. $D S D P, 17$ : Washington (U.S. Govt. Printing Office), 591-605.

Hein, J. R., Scholl, D. W., Barron, J. A., Jones, M. G., and Miller, J., 1978. Diagenesis of Late Cretaceous diatomaceous deposits and formation of the bottom simulating reflector in the Southern Bering Sea. Sedimentol., 25:155-181. 
Hein, J. R., Vallier, T. L., and Allan, M. A., 1981. Chert petrology and geochemistry, mid-Pacific mountains and Hess Rise, Deep Sea Drilling Project Leg 62. In Thiede, J., Vallier, T. L., et al., Init. Repts. DSDP, 62: Washington (U.S. Govt. Printing Office), 711-748.

Hein, J. R., and Yeh, H.-W., 1981. Oxygen-isotope composition of chert from the mid-Pacific mountains and Hess Rise, Deep Sea Drilling Project Leg 62. In Thiede, J., Vallier, T. L., et al., Init. Repts. DSDP, 62: Washington (U.S. Govt. Printing Office), 749-758.

Kastner, M., 1976. Diagenesis of basal sediments and basalts of Sites 322 and 323, Leg 35, Bellingshausen Abyssal Plain. In Hollister, C. D., Craddock, C., et al., Init. Repts. DSDP, 35: Washington (U.S. Govt. Printing Office), 513-528.

Kastner, M., Keene, J. B., and Gieskes, J. M., 1977. Diagenesis of siliceous oozes, I. Chemical controls on the rate of opal-A to opalCT transformation-an experimental study. Geochim. Cosmochim. Acta, 41:1041-1059.

Knauth, L. P., 1979. A model for the origin of chert in limestone. Geology, 7:274-277.

Knauth, L. P., and Epstein, S., 1975. Hydrogen and oxygen isotope ratios in silica from the Deep Sea Drilling Project. Earth Planet. Sci. Lett., 25:1-10.
1976. Hydrogen and oxygen isotope ratios in nodular and bedded cherts. Geochim. Cosmochim. Acta, 40:1095-1108.

Kolodny, Y., and Epstein, S., 1976. Stable isotope geochemistry of deep sea cherts. Geochim. Cosmochim. Acta, 40:1195-1209.

Lawrence, J. R., Drever, J. I., Anderson, T. F., and Brueckner, H. K., 1979. Importance of alteration of volcanic material in the sediments of Deep Sea Drilling Site 323: chemistry, ${ }^{18} \mathrm{O} /{ }^{16} \mathrm{O}$ and ${ }^{87} \mathrm{Sr} /{ }^{86} \mathrm{Sr}$. Geochim. Cosmochim. Acta, 43:573-588.

Levitan, M. A., Dontsova, E. I., Lisitsyn, A. P., and Bogdanov, Yu. A., 1975. The origin of chert in the sediments of the Pacific Ocean from data of oxygen isotopic analysis and a study of the distribution of chert. Geokhimiya, 3:420-430.

Murata, K. J., Friedman, I., and Gleason, J. D., 1977. Oxygen isotope relations between diagenetic silica minerals in Monterey Shale, Temblor Range, California. Am. J. Sci., 277:259-272.

Murata, K. J., and Norman, M. B., II, 1976. An index of crystallinity for quartz. Am. J. Sci., 276:1120-1130.

Pisciotto, K. A., 1978. Basinal sedimentary facies and diagenetic aspects of the Monterey Shale, California [Ph.D. dissert.]. University of California, Santa Cruz.

Taylor, H. P., Jr., and Epstein, S., 1962. Relationship between $\mathrm{O}^{18}$ / $\mathrm{O}^{16}$ ratios in coexisting minerals of igneous and metamorphic rocks, I, Principles and experimental results. Geol. Soc. Am. Bull., 73:461-480. 